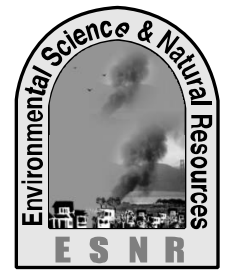

\title{
Effect of Pineapple Pulp on Sensory Quality and Shelf-life of Pineapple Cake
}

\author{
M. A. Haque ${ }^{1}$, S. Afrin ${ }^{1}$, A. Z.Shibly ${ }^{2 *}$, F. T. Zohora ${ }^{2}$ and M.M. Sultana ${ }^{3}$ \\ ${ }^{1}$ Department of Food Technology and Nutritional Science, \\ ${ }^{2}$ Department of Biotechnology and Genetic Engineering, \\ Mawlana Bhashani Science and Technology University, Tangail-1902 \\ ${ }^{3}$ Vrije Universiteit Brussel (VUB), Brussels, Belgium \\ *Corresponding author: zaffarshibly1987@gmail.com
}

\begin{abstract}
The experimental study on performance formulation and analysis of pineapple pulp fortified cake considering physical, chemical, sensorial and microbial quality. Cake was fortified with 5\%,10\%, 15\% and 20\% pineapple pulp incorporated into wheat flour. The pineapple pulps used in the cake preparation were analyzed for proximate composition. The physical and chemical properties of cakes were analyzed. Quantitive microbial analysis of food samples were done on the basis of total viable count. Bacterial load range from $1.22 \times 10^{2}\left(\mathrm{cfug}^{-1}\right)$ to $9.54 \times 10^{3}\left(\mathrm{cfug}^{-1}\right)$ on different storage condition. Zero present pineapple pulp incorporated cake sample showed the highest microbial load $9.54 \times 10^{3}\left(\mathrm{cfug}^{-1}\right)$.Total fungal count ranged from $0.97 \times 10^{2}$ to $5.04 \times 10^{3}\left(\mathrm{cfug}^{-1}\right)$ on different storage conditions. Fortified cake with $10 \%$ pineapple pulp contains lowest amount of fungi and bacteria after 8 days. So its shelf life will be enhanced about 6-7 days. Further 5\%, 15\%, and 20\% pineapple pulp incorporated cake sample contain high microbial load, hence they will get shelf life of 5-6 days. Fortification of cake with $5 \%, 10 \%, 15 \%, 20 \%$, pineapple pulp increasedthe value of ash, fiber and moisture in comparing with control cake. The statistical analysis of organoleptic test response of sensory attributes revealed that color, flavor, texture and overall acceptability were decreased with the increase of pineapple pulp in the cake formulation. Symmetry, crust and crumb quality, crust color and consistency,color,texture of the crumb and microbial load of the cakes containing $10 \%$ pulp were better than those of cakes containing above $10 \%$ pineapple pulp.
\end{abstract}

Key words: Fruit-cake, Pineapple pulp, Sensory quality, Shelf life

\section{Introduction}

Pineapple (Ananascomosus) belongs to the order Bromeliales, family Bromeliaceae, and subfamily Bromelioideae. The Bromeliaceae have adapted to a very wide range of habitats. They are monocots but are set apart from other monocots by several unique characters (Gilmartin and Brown, 1987). With a world production of more than 18 million tons in 2009, pineapple ranks $12^{\text {th }}$ among fruits crop worldwide (FAO, 2011).Based on the statistics (Anon., 2002) collected by Food and Agriculture Organization (FAO) of United Nations, mean pineapple production for 1999-2001 was $13,527,149$ metric tonnes (t) and was approximately constant for the 3 years. In international trade, the numerous pineapple cultivars are grouped in four main classes: 'Smooth Cayenne', 'Red Spanish', 'Queen', and 'Pernambuco (Abacaxi)' despite much variation in the types within each class(Morton, 1987). Pineapple is largely consumed around the world as canned pineapple slices, chunk and dice, pineapple juice, fruit salads, sugar syrup, alcohol, citric acid, pineapple chips and pineapple puree. Chunks of pineapple are used in desserts such as fruit salad, as well as in some savory dishes, including pizza toppings and a grilled ring on a hamburger. Crushed pineapple is used in yogurt, jam, sweets, and ice cream. The juice of the pineapple is popular and enjoyed over the world served as a beverage, and is also as a main ingredient in such cocktails (Deliza et al., 2005 and Fernandes et al., 2008). Pineapple contains nutrients which are good for human health, can used as a medicinal plantand a good source of Vitamin A, B and C (Sen et al.,1980). Pineapple contains the enzyme bromelain (protease) which has several therapeutic properties including malignant cell growth, thrombus formation, inflammation, control of diarrhoea, dermatological and skin debridement (Carvalho et al., 2008 and Tochi et al., 2008). A Pineapple cake contains these elevated amount of calories than plane cake along with the elevated amount of micronutrients. As well as, the acidic juice of pineapple increase the shelf life of fortified cake and its acceptability and palatability also increase without adding any artificial ingredients. These feature are normally absent in plane cake. The objective of our study was to increase energy, nutritious content, shelf life, acceptability and palatability in fortified cake. And take initiative to protect $\mathrm{Ca}$, phosphorous and vitamin $\mathrm{C}$ deficiency diseases. Plane cake and fortified cake A chunk of pineapple contain 82 (calories), $21 \mathrm{mg}$ Calcium, $150 \mathrm{mg}$ Phosphorous and $78 \mathrm{mg}$ Vit. C.

\section{Materials and Methods}

The experiment was conducted in the laboratory of the Department of Food Technology and Nutritional Science (FTNS) at Mawlana Bhashani Science and Technology University (MBSTU), Santosh, Tangail during December 2013 to November 2014. The raw materials were collected from the local market to produce consumer finished product in ñOne Agro Industryò bakery and stored in the laboratory. 


\section{Raw materials}

Commercially available wheat flour (Maida) and fully matured, sound, ripe, medium size, fresh pineapples were procured from local market of Tang ail. The pulp extracted from single variety of pineapple was used in this experiment. Egg, sugar, milk powder, baking powder and shortening (Soya bean oil) were used as raw materials.

\section{Extraction of pineapple pulp}

Fresh pineapple fruits were crowned and peeled after wash by tape water and were cut into two halves (length basis) then separated the true bulb from body. Then cut into pieces and pressed the pieces using a blender machine. The pulp was filtered through cheesecloth. The obtained pulp was packaged in air-tight poly propylene bags. The pulp was also stored at freezing temperature $\left(-6^{0} \mathrm{~F}\right)$ for further use.

Table 1. Basic formulation of pineapple pulp cake containing different $\%$ of pineapple pulp on $100 \mathrm{~g}$ flour weight basis

\begin{tabular}{|l|l|l|l|l|l|}
\hline Ingredients g100g & C-1 & C-2 & C-3 & C-4 & C-5 \\
\hline Wheat flour & 100 & 99 & 98 & 97 & 96 \\
\hline Egg & 35 & 35 & 35 & 35 & 35 \\
\hline Fat & 40 & 40 & 40 & 40 & 40 \\
\hline Sugar & 40 & 40 & 40 & 40 & 40 \\
\hline Baking powder & 3.5 & 3.5 & 3.5 & 3.5 & 3.5 \\
\hline Water & 50 & 46 & 42 & 38 & 34 \\
\hline Pineapple pulp & 0 & 5 & 10 & 15 & 20 \\
\hline
\end{tabular}

\section{Procedure for preparation of cake samples}

The flour, pulp and other ingredients for each cake were weighed accurately. At first egg, sugar, and vegetable oil were homogenized with an electric mixer at medium speed for 5 minutes. Next wheat flour, baking powder, skimmed milk powder and water were added to the mixture. The mixture was homogenized until it was uniform in consistency and the pineapple pulp was added. The cake batter was placed into aluminum pans, previously oiled and sprinkled with wheat flour, and baked in a conventional oven pre-heated to $180{ }^{\circ} \mathrm{C}$ for 25 minutes. After cooling, the cakes were weighed and sliced. The samples were taken, wrapped in plastic bags, and kept in a freezer at $\mathrm{i} 20^{\circ} \mathrm{C}$ and $4^{\circ} \mathrm{C}$ for further chemical analysis according to the method described by AACC (2002).

\section{Methods for proximate analysis of pineapple cake}

\section{Biochemical quality analysis}

All the samples were subjected to chemical quality assessment. Moisture was determined by ovendrying method, ash was determined by incineration method, fat was determined by soxhletappratus method, protein by Kjeldahl method and crude fiber and total sugar by AOAC-1990 method.

\section{Sensory analysis of pineapple cake}

Sensory evaluation of the experimental cakes was conducted after two hours of preparation by 20 panelists according to the method of Lawless and Heymann (1998). The samples were labeled with three digit numerals and presented to panelists. The symmetry and the characteristics of crust and crumb between the cakes prepared from incorporating with and without pineapple pulp were evaluated for color, flavor, and texture and over all acceptability by 20 testers. The panelists were selected from the teachers, scientific officers, students and employers of the Department of FTNS at MBSTU, Tangail and were briefed before evaluating sensory quality of the cakes. For statistical analysis of sensory data, a 1-9 point hedonic, rating test was used to assess the degree of acceptability of cake containing with different levels of pineapple pulp. Hedonic scale was in the following sequence: like extremely-9, like very much-8, like moderately-7, like slightly-6, neither like nor dislike-5, dislike slightly-4, dislike moderately-3,dislike very much-2, dislike extremely-1 were evaluated.

\section{Results and Discussion}

\section{Proximate composition of wheat flour and pineapple pulp}

Specific chemical-composition of wheat flour and pineapple pulp showed in Table 2. Although wheat flour composed of moisture $(13.09 \%)$, protein $(12.56 \%)$, fat $(1.6 \%)$, ash $(0.62 \%)$, fiber $(0.68 \%)$ and carbohydrate $(72.13 \%)$ where pineapple pulp moisture $(81 \%)$, protein $(2.6 \%)$, fat $(1.02 \%)$, ash $(0.91 \%)$, fiber $(0.73 \%)$ and carbohydrate $(14.47 \%)$.

\section{The effect of pineapple pulp on the chemical} composition of cake

The highest (7.56\%) and lowest (5.32\%) Protein content found in the cake fortified with $0 \%$ pineapple pulp and $20 \%$ pineapple pulp cake, respectively. Whereas $10 \%$ pineapple pulp cake had $5.45 \%$ Protein content. The highest $(19.27 \%)$ and lowest $(18.95 \%)$ fat content found in the cake fortified with $15 \%$ pineapple pulp and $5 \%$ pineapple pulp cake, respectively. Whereas $10 \%$ pineapple pulp cake had $19.18 \%$ fat content. The highest (1.52\%) and lowest (1.16\%) ash content found in the cake fortified with $20 \%$ pineapple pulp and $0 \%$ pineapple pulp cake, respectively. Whereas, $10 \%$ pineapple pulp cake had $1.32 \%$ ashes content. The highest $(2.68 \%)$ and lowest $(0.92 \%)$ crude fiber content found in the cake fortified with $20 \%$ pineapple pulp and $0 \%$ pineapple pulp cake, respectively. Whereas $10 \%$ pineapple pulp cake had $1.80 \%$ crude fiber content. The highest $(50.83 \%)$ and lowest $(48.05 \%)$ carbohydrate content found in the cake fortified with $0 \%$ pineapple pulp and $20 \%$ pineapple pulp cake, respectively. 
Table 2. Chemical composition of wheat flour and pineapple pulp

\begin{tabular}{|l|l|l|}
\hline Component $\%$ & Wheat flour & Pineapple pulp \\
\hline Moisture & 13.09 & 81 \\
\hline Protein & 12.56 & 2.6 \\
\hline Fat & 1.6 & 1.02 \\
\hline Ash & 0.62 & 0.91 \\
\hline Fiber & 0.68 & 0.73 \\
\hline carbohydrate & 72.13 & 14.47 \\
\hline
\end{tabular}

Whereas, $10 \%$ pineapple pulp cake had $49.71 \%$ carbohydrate content.The highest $(25.88 \%)$ and lowest $(21.5 \%)$ moisture content found in the cake fortified with $20 \%$ pineapple pulp and $0 \%$ pineapple pulp cake, respectively. Whereas, $10 \%$ pineapple pulp cake had $24.34 \%$ moisture content. The highest $(404.11 \mathrm{kcal})$ and lowest $(386.55 \mathrm{kcal})$ energy found in the cake fortified with $0 \%$ pineapple pulp and $20 \%$ pineapple pulp cake respectively. Whereas, $10 \%$ pineapple pulp cake containing $393.26 \mathrm{kcal}$ energy.

Table 3. Chemical composition of control cake and experimental cake incorporated with pineapple pulp at different level

\begin{tabular}{|c|c|c|c|c|c|}
\hline${\text { Ingredients g } 100 \mathrm{~g}^{-1}}^{-1}$ & $\mathrm{C}-1$ & $\mathrm{C}-2$ & $\mathrm{C}-3$ & $\mathrm{C}-4$ & $\mathrm{C}-5$ \\
\hline Protein \% & 7.56 & 5.50 & 5.45 & 5.41 & 5.32 \\
\hline Fat \% & 19.13 & 18.95 & 19.18 & 19.27 & 19.23 \\
\hline Ash \% & 1.16 & 1.22 & 1.32 & 1.46 & 1.52 \\
\hline Fiber \% & 0.92 & 1.36 & 1.80 & 2.24 & 2.68 \\
\hline Carbohydrate \% & 50.83 & 50.21 & 49.71 & 48.98 & 48.05 \\
\hline Moisture \% & 21.5 & 23.94 & 24.34 & 24.88 & 25.88 \\
\hline Energy (kcal) & 404.11 & 395.01 & 393.26 & 390.99 & 386.55 \\
\hline Energy from fat(kcal) & 172.17 & 170.55 & 172.62 & 173.43 & 173.07 \\
\hline
\end{tabular}

*All figures are mean of 3 replications. In this study the cake sample represents as, $C-1=0 \%$ (control), $C-2=5 \%, C-3=$ $10 \%$, cake, $C-4=15 \%$ and $C-5=20 \%$ pineapple pulp containing cake, respectively

\section{pH}

$\mathrm{pH}$ content of pineapple cake at different pulp level e.g. $0 \%, 5 \%, 10 \%, 15 \%$ and $20 \%$ showed in Fig. 1 . The highest $\mathrm{pH} 7.5$ and lowest $\mathrm{pH} 6.1$ found in the cake fortified with $0 \%$ pineapple pulp and $20 \%$ pineapple pulp cake respectively. Whereas, $10 \%$ pineapple pulp fortified cake contained $\mathrm{pH}$ 6.5. In case of C-1 that acts as a control containedpH 7.5 because it containing no pulp.On the other hand $10 \%$ pineapple pulp fortified fruits cake contained decreased $\mathrm{pH} 6.5$ because Pineapple pulp is acidic in nature, it helps to decrease the $\mathrm{pH}$ of fortified cake. As the level of PP increase it leads the gradual decrease of fortified cake $\mathrm{pH}$.

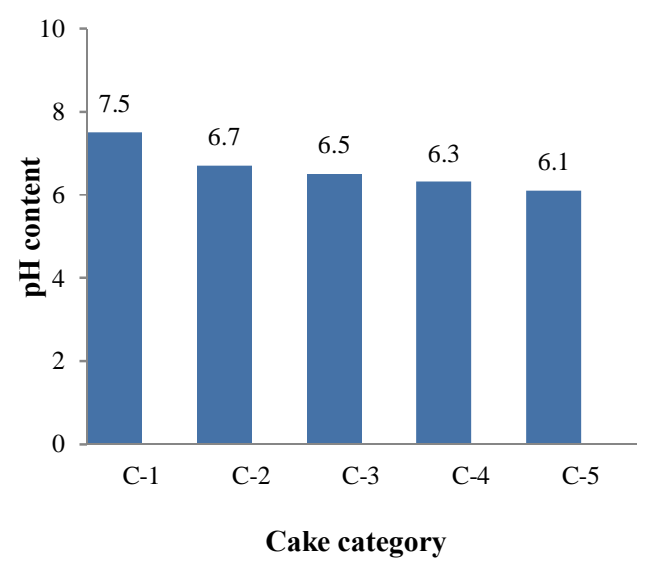

Fig. 1. pH content of pineapple cake at different pulp level (all values are meaning of three replications)

\section{Microbial analysis}

Total bacterial count at room temperature of pineapple cake

Total bacterial count at room temperature of pineapple cake (i.e. $0 \%, 5 \%, 10 \%, 15 \%$ and $20 \%$ ) at several storage (i.e. $1 \mathrm{st}, 2^{\text {nd }}, 3^{\text {rd }}$ and $4^{\text {th }}$ day) periods showed in Table 4. Bacterial load at room temperature (Day-1to Day-4) ranged from $1.22 \times 10^{2}$ to $9.54 \times 10^{3} \mathrm{cfu} \mathrm{g}^{-1}$. Highest bacterial load found in $0 \%$ pineapple pulp cake in Day-4 $\left(9.54 \times 10^{3} \mathrm{cfug}^{-1}\right)$. Lowest bacterial load found in $10 \%$ pineapple pulp cake in Day-1 $\left(1.22 \times 10^{2} \mathrm{cfug}^{-1}\right)$.

Total bacterial count at refrigeration temperature of pineapple cake

Total bacterial count at refrigeration temperature of Pineapple cake (i.e. $0 \%, 5 \%, 10 \%, 15 \%$ and 20\%) at several storage (i.e. $2^{\text {nd }}, 4^{\text {th }}$ and $6^{\text {th }}$ day) period showed in Table 4.Bacterial load (i.e. $2^{\text {nd }}, 4^{\text {th }}$ and $6^{\text {th }}$ day) ranged from $1.36 \times 10^{2}$ to $6.71 \times 10^{3} \mathrm{cfug}^{-1}$. Highest bacterial load found in $0 \%$ pineapple pulp cake in Day-6 $\left(6.71 \times 10^{3} \mathrm{cfug}^{-1}\right)$. Lowest bacterial load found in $10 \%$ pineapple pulp cake in Day-2 $\left(1.36 \times 10^{2} \mathrm{cfug}^{-1}\right)$.

Total fungal count at room temperature of pineapple cake

Total fungal count at room temperature of pineapple cake (i.e. $0 \%, 5 \%, 10 \%, 15 \%$ and $20 \%$ ) at several storage (i.e. $1^{\text {st }}, 2^{\text {nd }}, 3^{\text {rd }}$ and $4^{\text {th }}$ day) periods showed in Table 5. Fungal load at room temperature (Day-1 to Day-4) ranged from $1.16 \times 10^{2}$ to $3.79 \times 10^{3} \mathrm{cfug}^{-1}$. Highest fungal load found in $0 \%$ pineapple pulp cake in Day-4 $\left(3.79 \times 10^{3} \mathrm{cfug}^{-1}\right)$. Lowest fungal load found in $10 \%$ pineapple pulp cake in Day-1 $\left(1.16 \times 10^{2} \mathrm{cfug}^{-1}\right)$. 
Table 4. Total bacterial count $\left(\mathrm{cfu} \mathrm{g}^{-1}\right)$ at room and refrigeration temperature

\begin{tabular}{|l|l|l|l|l|l|l|l|}
\hline \multirow{2}{*}{$\begin{array}{l}\text { \% of } \\
\text { substitution }\end{array}$} & \multicolumn{3}{|l|}{ Total Bacterial count $\left(\mathrm{cfug}^{-1}\right)$ at room temperature } & \multicolumn{2}{l|}{$\begin{array}{l}\text { Total Bacterial count }\left(\mathrm{cfug}^{-1}\right) \text { at }^{2} \\
\text { Refrigeration Temperature }\end{array}$} \\
\cline { 2 - 8 } & Day -1 & Day-2 & Day-3 & Day-4 & Day -2 & Day-4 & Day-6 \\
\hline $0 \%$ PP & $1.34 \times 102$ & $4.02 \times 10^{3}$ & $7.56 \times 10^{3}$ & $9.54 \times 10^{3}$ & $1.57 \times 10^{2}$ & $5.78 \times 10^{3}$ & $6.71 \times 10^{3}$ \\
\hline $5 \%$ PP & $1.25 \times 102$ & $3.74 \times 10^{3}$ & $4.83 \times 10^{3}$ & $8.42 \times 10^{3}$ & $1.49 \times 10^{2}$ & $4.36 \times 10^{3}$ & $5.83 \times 10^{3}$ \\
\hline $10 \%$ PP & $1.22 \times 102$ & $1.98 \times 10^{3}$ & $2.44 \times 10^{3}$ & $4.68 \times 10^{3}$ & $1.36 \times 10^{2}$ & $3.95 \times 10^{3}$ & $4.96 \times 10^{3}$ \\
\hline $15 \%$ PP & $1.57 \times 102$ & $2.34 \times 10^{3}$ & $3.52 \times 10^{3}$ & $5.14 \times 10^{3}$ & $1.41 \times 10^{2}$ & $4.33 \times 10^{3}$ & $5.92 \times 10^{3}$ \\
\hline $20 \%$ PP & $1.84 \times 102$ & $2.40 \times 10^{3}$ & $3.63 \times 10^{3}$ & $6.21 \times 10^{3}$ & $1.52 \times 10^{2}$ & $4.42 \times 10^{3}$ & $6.29 \times 10^{3}$ \\
\hline
\end{tabular}

$P P=$ Pineapple pulp, all figures are mean of 3 replications

Table 5. Total fungal count $\left(\mathrm{cfug}^{-1}\right)$ at room and refrigeration temperature

\begin{tabular}{|l|l|l|l|l|l|l|l|}
\hline \multirow{2}{*}{$\begin{array}{c}\text { \% of } \\
\text { substitution }\end{array}$} & \multicolumn{4}{|c|}{$\begin{array}{c}\text { Total Fungal count }\left(\mathrm{cfug}^{-1}\right) \text { at room } \\
\text { temperature }\end{array}$} & \multicolumn{3}{c|}{$\begin{array}{c}\text { Total } \\
\text { Fungal count }\left(\mathrm{cfug}^{-1}\right) \text { at refrigeration } \\
\text { Temperature }\end{array}$} \\
\cline { 2 - 8 } & Day -1 & Day-2 & Day-3 & Day-4 & Day -2 & Day-4 & Day-6 \\
\hline $0 \%$ PP & $1.89 \times 10^{2}$ & $2.49 \times 10^{3}$ & $2.96 \times 10^{3}$ & $3.79 \times 10^{3}$ & $1.62 \times 10^{2}$ & $3.61 \times 10^{3}$ & $5.04 \times 10^{3}$ \\
\hline $5 \%$ PP & $1.63 \times 10^{2}$ & $2.38 \times 10^{3}$ & $2.85 \times 10^{3}$ & $3.64 \times 10^{3}$ & $1.30 \times 10^{2}$ & $3.53 \times 10^{3}$ & $4.93 \times 10^{3}$ \\
\hline $10 \%$ PP & $1.16 \times 10^{2}$ & $2.14 \times 10^{3}$ & $2.51 \times 10^{3}$ & $3.48 \times 10^{3}$ & $0.97 \times 10^{2}$ & $3.16 \times 10^{3}$ & $4.38 \times 10^{3}$ \\
\hline $15 \%$ PP & $1.37 \times 10^{2}$ & $2.21 \times 10^{3}$ & $2.63 \times 10^{3}$ & $3.53 \times 10^{3}$ & $1.24 \times 10^{2}$ & $3.27 \times 10^{3}$ & $4.42 \times 10^{3}$ \\
\hline $20 \%$ PP & $1.56 \times 10^{2}$ & $2.32 \times 10^{3}$ & $2.82 \times 10^{3}$ & $3.57 \times 10^{3}$ & $1.38 \times 10^{2}$ & $3.36 \times 10^{3}$ & $4.63 \times 10^{3}$ \\
\hline
\end{tabular}

$P P=$ Pineapple pulp, all figures are mean of 3 replications

\section{Total fungal count at refrigeration temperature of} pineapple cake

Total fungal count at refrigeration temperature of pineapple cake (i.e. $0 \%, 5 \%, 10 \%, 15 \%$ and $20 \%$ ) at several storage (i.e. $2^{\text {nd }}, 4^{\text {th }}$ and $6^{\text {th }}$ day) periods shown in Table4. Fungal load at refrigeration temperature (i.e. $2^{\text {nd }}, 4^{\text {th }}$ and $6^{\text {th }}$ day) ranged from $1.24 \times 10^{2}$ to $5.04 \times 10^{3} \mathrm{cfug}^{-1}$. Highest fungal load found in $0 \%$ pineapple pulp cake in Day-6 $\left(5.04 \times 10^{3} \mathrm{cfug}^{-1}\right)$. Lowest fungal load found in $15 \%$ pineapple pulp cake in Day-2 $\left(1.24 \times 10^{2} \mathrm{cfug}^{-1}\right)$.
Volume, weight and specific volume of the cake

Volume and Specific volume content of pineapple cake at different pulp level e.g. $0 \%, 5 \%, 10 \%, 15 \%$ and $20 \%$ showed in Table 6 . The highest $(180 \mathrm{cc})$ and lowest $(165 \mathrm{cc})$ volume content found in the cake fortified with $0 \%$ pineapple pulp and $20 \%$ pineapple pulp cake, respectively. Whereas, $10 \%$ pineapple pulp cake had $173 \mathrm{cc}$ volume content. The highest $\left(1.66 \mathrm{cc} \mathrm{g}^{-1}\right)$ and lowest $\left(1.47 \mathrm{cc} \mathrm{g}^{-1}\right)$ specific volume content found in the cake fortified with $0 \%$ pineapple pulp and $20 \%$ pineapple pulp cake respectively. Whereas $10 \%$ pineapple pulp cake had $1.57 \mathrm{cc} \mathrm{g}^{-1}$ specific volumes content.

Table 6. Effect of pineapple pulp on volume, weight and specific volume of the cake

\begin{tabular}{|c|c|c|c|}
\hline \% of substitution & Volume $(\mathrm{cc})$ & Weight $(\mathrm{g})$ & Specific volume $\left(\mathrm{cc} \mathrm{g}^{-1}\right)$ \\
\hline $0 \% \mathrm{PP}($ Control $)$ & $180^{\mathrm{a}}$ & $108^{\mathrm{e}}$ & $1.66^{\mathrm{a}}$ \\
\hline $5 \% \mathrm{PP}$ & $176^{\mathrm{a}}$ & $109^{\mathrm{d}}$ & $1.61^{\mathrm{ab}}$ \\
\hline $10 \% \mathrm{PP}$ & $173^{\mathrm{b}}$ & $110^{\mathrm{c}}$ & $1.57^{\mathrm{abc}}$ \\
\hline $15 \% \mathrm{PP}$ & $170^{\mathrm{b}}$ & $111^{\mathrm{b}}$ & $1.47^{\mathrm{c}}$ \\
\hline $20 \% \mathrm{PP}$ & $165^{\mathrm{c}}$ & $112^{\mathrm{a}}$ & 0.059 \\
\hline $\mathrm{LSD}(0.05)$ & 4.970 & 1.331 & 2.13 \\
\hline $\mathrm{CV}(\%)$ & 0.43 & 0.18 & are not \\
*PP= Pineapple Pulp **All figures are average of three replications. Mean in column having the same letters are
\end{tabular}
significantly different at $5 \%$ probability level $(P<0.05)$ by DMART

Table 7. Effect of pineapple pulp on color, flavor, texture and overall acceptability of cake

\begin{tabular}{|l|c|c|c|c|}
\hline \multirow{2}{*}{$\%$ of substitution } & \multicolumn{3}{|c|}{ Mean scores on } \\
\cline { 2 - 5 } & Color & Flavor & Texture & Overall acceptability \\
\hline $0 \%$ PP (Control) & $8.15^{\mathrm{a}}$ & $8.05^{\mathrm{a}}$ & $8.40^{\mathrm{a}}$ & $8.05^{\mathrm{a}}$ \\
\hline $5 \%$ PP & $7.10^{\mathrm{b}}$ & $6.95^{\mathrm{ab}}$ & $7.00^{\mathrm{bc}}$ & $6.85^{\mathrm{ab}}$ \\
\hline $10 \%$ PP & $7.40^{\mathrm{b}}$ & $7.90^{\mathrm{a}}$ & $7.55^{\mathrm{b}}$ & $7.40^{\mathrm{a}}$ \\
\hline $15 \%$ PP & $6.55^{\mathrm{c}}$ & $6.90^{\mathrm{ab}}$ & $6.40^{\mathrm{c}}$ & $6.05^{\mathrm{b}}$ \\
\hline $20 \%$ PP & $5.70^{\mathrm{d}}$ & $6.20^{\mathrm{b}}$ & $5.15^{\mathrm{d}}$ & $4.50^{\mathrm{c}}$ \\
\hline LSD $(0.05)$ & 0.434 & 1.096 & 0.613 & 1.075 \\
\hline CV $(\%)$ & 3.31 & 8.09 & 4.71 & 8.87 \\
\hline
\end{tabular}

${ }^{*} P P=$ Pineapple Pulp**All figures are average of three replications. Mean in column having the same letters are not significantly different at $5 \%$ probability level $(P<0.05)$ by DMART 


\section{The effect of pineapple pulp on sensory quality of} cake

Effect of pineapple pulp on sensory quality as color, flavor, texture and overall acceptability of the cake at different pulp level (i.e. $0 \%, 5 \%, 10 \%, 15 \%$ and 20\%) showed in Table 7 . The highest score on color (8.15), flavor (8.05), texture (8.40), overall acceptability (8.05) found in the cake fortified with $0 \%$ pineapple pulp. The lowest color (5.7), flavor (6.2), texture (5.15), overall acceptability (4.50) score found in the cake fortified with $20 \%$ pineapple pulp. The score on color (7.40), flavor (7.90), texture (7.55), overall acceptability (7.40) found in the cake fortified with $10 \%$ pineapple pulp. (Mean in column having the same letters is not significantly different at $5 \%$ probability level by DMART.

\section{References}

Anon, 2002. FAOSTATD at abase. Food and Agriculture Organization of the United Nations, Rome, Italy.

AACC (American Association of Cereal Chemists). 2000. Approved Methods. Published by the American Association of Cereal Chemists, $10^{\text {th }}$ Ed., St. Paul, MN. USA.

AOAC, 1990. Official methods of Analysis of AOAC, International, Washington, DC: Association of Official Analytical Chemist, 16: 1546.

Carvalho, J. M.; Miranda, C. I. and Bento, C. A. 2008. A study of retention of sugars in the process of clarification of pineapple juice (Ananascosmosus, L. Merril) by micro- and ultra-filtration.Journal of Food Engineering, 87: 447-454.

Deliza, R.; Rosenthal, A.; Abadio, F. B. D.; Silva, C. H. O. and Castillo, C. 2005. Utilization of pineapple waste from juice processing industries: Benefits perceived by consumers. Journal of Food Engineering, 67(1-2): 241246.

\section{Conclusions}

In this experiment, analysis of physical and chemical properties showed that, fortified cake with $5 \%, 10 \%, 15 \%$ and $20 \%$ pineapple pulp increased the values of ash, fiber and moisture in comparing with control cake.Cake fortified with $10 \%$ pineapple pulpsample containedlowest amount of microorganisms and its shelf-life enhanced about 67 days. And the sensory attributes revealed that color, flavor, texture and overall acceptability were better in $10 \%$ pulp containing cake than those containing below and above $10 \%$ pineapple pulp.

Fernandes, F. A. N.; JrLinhares, F. E. and Rodrigues, S. 2008. Ultrasound as pretreatment for drying of pineapple.Ultrasonic SonoChemistry, 15: 1049-1054.

Gilmartin, A. J. and Brown, G. K. 1987. Bromeliales, related monocots, and resolution of relationships among Bromeliaceae subfamilies. Systematic Botany, 12: 493-500.

Morton, J. 1987. Fruits of warm climates. Creative Resource Systems, Inc. NC.pp. 18-28.

Sen, S. K.; Roy, A. and Bose, T. K. 1980.Pineapple Production and Utilization, Calcutta, pp.13-23.

Tochi, B. N.; Wang, Z.; Xu, S. Y.and Zhang, W. 2008. Therapeutic Application of pineapple protease (Bromelain): A Review. Pakistan Journal of Nutrition, 7(4): 513-520. 